\title{
Management of browse plants as drought fodder for sheep: a preliminary study
}

\author{
S. OPPONG ${ }^{1}$, P.D. KEMP ${ }^{1}$, G.B. DOUGLAS ${ }^{2}$ and B.T. BULLOCH ${ }^{3}$ \\ ${ }^{1}$ Department of Plant Science, Massey University, Palmerston North \\ ${ }^{2}$ AgResearch Grasslands, Private Bag 11008, Palmerston North \\ ${ }^{3}$ PO Box 7097, Palmerston North
}

\section{Abstract}

Two experiments were designed to provide practical guidelines to improve the effective use of browse plants as ruminant feed, especially during dry summers. The effects of planting stock and cutting management on forage yield and quality of Tangoio hybrid willow (Salix matsudana x alba), Kinuyanagi willow (Salix kinuyanagi) and erect dorycnium (Dorycnium rectum), a small leguminous shrub, were determined over one summer from 1 - and 3-year-old trees. Experiment 1 was arranged as a $2 \times 2$ factorial with 2 species and 2 planting stock in 5 randomised complete blocks. Experiment 2 was also arranged as a split plot design with cutting heights allocated to main plots and species $\times$ frequency to sub-plots in 3 randomised complete blocks. At the hill country site (Ballantrae), the yields of Tangoio (66 g DM/tree) and Kinuyanagi (27 g DM/tree) were low, owing probably to the low soil nutrient status and the harsh climatic conditions. Poor regrowth after the summer harvest at Ballantrae suggested that willows can be utilised only once during the growing season in such environments. At the lowland site (Aokautere), Tangoio was higher yielding $(\mathrm{P}<0.05)$ than Kinuyanagi, with erect dorycnium the lowest yielding. Erect dorycnium was ineffective as drought fodder in the Manawatu owing to its relatively low yield. Tree forage digestibility and total nitrogen content were higher in Tangoio than Kinuyanagi $(\mathrm{P}<0.05)$ but were not affected by stock type and cutting height. Harvesting twice during the growing season increased the edible forage yield by $27 \%(\mathrm{P}<0.05)$. Total condensed tannin content was higher in Kinuyanagi than Tangoio, a possible disadvatange. Unrooted stem cuttings were as productive as rooted cuttings $(\mathrm{P}>0.05)$ and are cheaper to establish. Tangoio and Kinuyanagi have potential as drought fodder in addition to their traditional roles in soil conservation and rehabilitation.

Keywords: browse, cutting management, Dorycnium rectum, multipurpose trees, planting stock, Salix kinuyanagi, Salix matsudana $\mathrm{x}$ alba

\section{Introduction}

In New Zealand, ruminant production is based on the grazing of temperate pastures consisting mainly of perennial ryegrass and white clover. Yield and quality of these pastures frequently declines in summer and autumn, especially in areas prone to drought. Herbaceous feed shortage in dry periods, particularly in hill country, may be ameliorated by using browse shrubs and trees (Lambert et al. 1989).

Although browse shrubs and trees have potential for increasing animal feed supply and quality, their use is hampered by management difficulties. Two experiments are reported that are part of a programme aimed at providing practical guidelines for overcoming some of the management difficulties impeding the effective use of browse plants as ruminant feed, especially during dry summers. These experiments aimed to determine the effects of planting stock and cutting management on forage yield and quality of Tangoio hybrid willow, Kinuyanagi willow and erect dorycnium, a small leguminous shrub. These species are already being used on farms for soil conservation and rehabilitation (van Kraayenoord \& Hathaway 1986), and their use as browse will enhance their multipurpose status.

\section{Materials and methods}

\section{Plant species}

The species used were: Tangoio hybrid willow (Salix matsudana Koidz. x alba L.) and Kinuyanagi willow (Salix kinuyanagi) in experiment 1 and the two willow species and erect dorycnium (Dorycnium rectum L Ser. in DC) in experiment 2 . These species are fully described by Douglas et al. (1996).

\section{Experiment 1}

Effect of planting stock on forage yield and quality of two willows

The experiment was conducted at AgResearch's Ballantrae Hill Country Research Station (grid reference; NZMS1, Woodville N149/304413). The mean annual rainfall is $1210 \mathrm{~mm}$, most falling in winter. The drier months are January to April. The soil was a Wianui silt loam, poorly drained and low in soil nutrients (e.g., Olsen P $8 \mathrm{mg} / \mathrm{kg}$ soil). 
The two species of willow were used. Each species had 2 planting stocks: 1 -year-old rooted stem cuttings and sheep poles $(2.2 \mathrm{~m}$ long $\times 4.0-6.0 \mathrm{~cm}$ diameter unrooted stem cuttings). They were planted in October 1993 at a spacing of $5 \mathrm{~m}$ centres. The experiment was arranged as a $2 \times 2$ factorial with 2 species and 2 planting stock in 5 randomised complete blocks. There were 4 trees per plot. All plants were fitted with plastic "netlon" sleeves $1.4 \mathrm{~m}$ high to protect them against bark damage by grazing animals. The paddock was regularly grazed with sheep. Pasture around the base of the trees was killed with a mixture of glyphosate, terbuthylazine and terbumeton (1.1, 0.25 and $0.25 \mathrm{~kg}$ ai/ha, respectively). In August 1994 all the trees were topped at a height of $1.6 \mathrm{~m}$.

\section{Experiment 2}

Effect of cutting height and harvesting times on forage yield and quality of two willows and erect dorycnium

The experiment was conducted on a cool, moist, lowland site at the Horticultural Research Institute's field station at Aokautere (grid reference; NZMS1, Palmerston North $\mathrm{N} 149 / 148345)$. The mean annual rainfall is $991 \mathrm{~mm}$ with distribution similar to that at Ballantrae. The soil was a Manawatu silt loam, freely drained but subject to surface compaction and with medium fertility (e.g., Olsen P $17 \mathrm{mg} / \mathrm{kg}$ soil).

The two willows and erect dorycnium were planted in late June 1991. These plants were harvested at 3 heights above ground (control, $80 \mathrm{~cm}$, and $120 \mathrm{~cm}$ ) and once (January 1995) or twice (January and April 1995). The control heights were $10 \mathrm{~cm}$ (erect dorycnium) and $30 \mathrm{~cm}$ (Tangoio and Kinuyanagi). On 12 August 1994, all trees were cut to the above heights and the crowns trimmed to various widths depending on cutting height. The crown widths were 10 and $30 \mathrm{~cm}$ (erect dorycnium) and 30 and $60 \mathrm{~cm}$ (Tangoio and Kinuyanagi) for the control, 80 and $120 \mathrm{~cm}$ heights respectively. The pasture between browse plant rows was mowed regularly and that within rows was sprayed with glyphosate $(1.1 \mathrm{~kg}$ ai/ ha).

The experiment was arranged as a split plot design with cutting heights allocated to main plots and species $\mathrm{x}$ frequency to sub-plots in 3 randomised complete blocks. Each sub-plot consisted of a row of 4-8 plants with intra-row spacing of $1.5 \mathrm{~m}$ and between-row spacing of $2.5 \mathrm{~m}$.

\section{Measurements}

In experiment 1 , the two central trees in the row of four were harvested in summer and autumn on 20 January and 5 April 1995 respectively. Yields in autumn were negligible and were therefore not used in the statistical analysis. In experiment 2 , trees were harvested on 20-25
January and 3 April 1995. Two randomly selected trees were harvested from each plot. The fresh weight was measured and the herbage subsampled and dissected into leaf, edible stem (soft stems $<5 \mathrm{~mm}$ in diameter) and woody stem. These were oven-dried at $80^{\circ} \mathrm{C}$ for 24 hours to determine the dry weight of each component. Pasture yield was measured from October 1994 to May 1995 by harvesting herbage within randomly allocated cages $(5 \times$ $0.186 \mathrm{~m}^{2}$ ) between trees at monthly intervals, using a pretrimming technique. Harvested pasture was sub-sampled, separated into botanical components and their dry weight determined after oven-drying at $80^{\circ} \mathrm{C}$ for 24 hours.

\section{Chemical analyses}

Sub-samples of leaf and edible stem from each species and from pasture, in summer and autumn, were stored at $-20^{\circ} \mathrm{C}$ and then freeze-dried and ground to pass through a $1 \mathrm{~mm}$ sieve. All samples were analysed for total nitrogen (Automatic Kjeldahl method - macro; AOAC 1984), in vitro digestibility (Roughan \& Holland 1977) and condensed tannin by a modified butanol$\mathrm{HCl}$ procedure (Terrill et al. 1992). Condensed tannin levels were determined only for the willow species.

\section{Statistical analyses}

PROC GLM in the Statistical Analysis System programme (SAS 1988) was used for all analyses. Treatment means were subjected to the least significance difference test.

\section{Results}

\section{Experiment 1}

Dry matter yield. There were significant differences between species in total dry matter (DM) and edible forage (leaf plus stem $<5 \mathrm{~mm}$ ) yields for the summer harvest (Table 1). Tangoio yielded 50\% more than Kinuyanagi. Yields were similar between planting stocks in both species. In autumn, mean DM yields of Tangoio were $9 \mathrm{~g} \mathrm{DM} /$ tree and $8 \mathrm{~g} \mathrm{DM} /$ tree for unrooted and rooted stem stocks, respectively. DM yield of Kinuyanagi was zero in autumn.

Forage quality. Tangoio was more digestible than Kinuyanagi but total nitrogen content was similar for the two species (Table 1). Unrooted stem cuttings of Tangoio had slightly higher total nitrogen content than rooted cuttings. Condensed tannin (CT) level was apparently higher in Kinuyanagi than in Tangoio but not statistically tested.

\section{Experiment 2}

Dry matter yield. Tangoio had higher total DM and edible forage yields per tree than erect dorycnium, with 
Table 1 Effect of planting stock, rooted (RSC) and unrooted (USC) stem cuttings on forage yield and quality of willows during spring growth at Ballantrae. OMD, organic matter digestibility; CT, condensed tannins.

\begin{tabular}{|c|c|c|c|c|c|c|c|c|c|c|}
\hline \multirow{3}{*}{ Species } & \multicolumn{4}{|c|}{$\ldots$ Yield (g DM/tree) } & 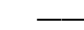 & & \multirow{2}{*}{\multicolumn{2}{|c|}{$\begin{array}{c}\text { Nutritive value (g/kg DM) } \\
\text { OMD }\end{array}$}} & \multirow{2}{*}{\multicolumn{2}{|c|}{ Total CT }} \\
\hline & \multicolumn{2}{|c|}{$\begin{array}{l}\text { Total dry } \\
--- \text { matter --- }\end{array}$} & \multirow{2}{*}{\multicolumn{2}{|c|}{$\begin{array}{l}\text { Total edible } \\
\text {--- forage }\end{array}$}} & \multicolumn{2}{|c|}{$\begin{array}{c}\text { Total } \\
\text {--- nitrogen }\end{array}$} & & & & \\
\hline & $\begin{array}{l}---m \\
R S C\end{array}$ & er --- & & & & $\begin{array}{l}\text { yen --- } \\
\text { USC }\end{array}$ & RSC & USC & RSC & USC \\
\hline Kinuyanagi willow & 26 & 28 & 19 & 22 & 10.5 & 10.2 & 630 & 615 & 265 & 310 \\
\hline Tangoio willow & 58 & 74 & 37 & 41 & 10.9 & 12.2 & 680 & 685 & 145 & 165 \\
\hline LSD $(P<0.05)$ & \multicolumn{2}{|c|}{15} & \multicolumn{2}{|c|}{8} & \multicolumn{2}{|c|}{1.1} & \multicolumn{2}{|c|}{16} & \multicolumn{2}{|c|}{ nd } \\
\hline
\end{tabular}

nd, not determined.

Kinuyanagi intermediate (Table 2). The percentage of DM that was edible forage above winter cut height was 39\%, 43\% and $68 \%$ for Kinuyanagi, Tangoio and erect dorycnium respectively. DM yield of all browse species was unaltered by cutting height. Total DM and edible forage yields from the three cutting heights were (control) $1.5 \mathrm{~kg} \mathrm{DM} /$ tree and $0.7 \mathrm{~kg} \mathrm{DM} /$ tree, $(80 \mathrm{~cm}) 2.2 \mathrm{~kg}$ $\mathrm{DM} /$ tree and $1.0 \mathrm{~kg} \mathrm{DM} /$ tree, and $(120 \mathrm{~cm}) 1.9 \mathrm{~kg} \mathrm{DM} /$ tree and $0.9 \mathrm{~kg}$ $\mathrm{DM} /$ tree $(\mathrm{P}>0.05$, unpublished data). Harvesting times affected only total edible forage yield, with the summer plus autumn harvests (1.0 kg DM/tree) outyielding the summer only harvest $(0.7 \mathrm{~kg}$ $\mathrm{DM} /$ tree) $(\mathrm{P}<0.05$, unpublished data).

Forage quality. Tangoio had higher $(\mathrm{P}<$ $0.05)$ total nitrogen content and organic matter digestibility than Kinuyanagi (Table 2). Nitrogen content of erect dorycnium was higher than both willow species. The total CT content in Kinuyanagi $(255 \mathrm{~g} / \mathrm{kg}$ DM) was four times higher than in Tangoio (60 g/kg DM) (Table 2).

Edible forage yield during the harvesting periods. The order from greatest to least yield of edible forage per hectare was Tangoio, Kinuyanagi, erect dorycnium and pasture (Table 3 ).

\section{Discussion}

In both experiments, the browse species provided good quality supplementary feed in a dry summer and autumn. Tangoio consistently outyielded Kinuyanagi in total DM and edible forage yields (above cutting height). These results were in contrast to those reported by Douglas et al. (1996) who found total and edible DM
Table 2 Effect of cutting management on forage yield and quality of willows and erect dorycnium over one growing season at Aokautere. OMD, organic matter digestibility; CT, condensed tannins.

\begin{tabular}{lccccc}
\hline Species & \multicolumn{2}{c}{ Yield (g DM/tree) } & \multicolumn{3}{c}{ Nutritive value (g/kg DM) } \\
& $\begin{array}{c}\text { Total dry } \\
\text { matter }\end{array}$ & $\begin{array}{c}\text { Total edible } \\
\text { forage }\end{array}$ & $\begin{array}{c}\text { Total } \\
\text { nitrogen }\end{array}$ & OMD & Total CT \\
\hline Kinuyanagi willow & 2.1 & 0.8 & 17.2 & 615 & 255 \\
Tangoio willow & 2.5 & 1.1 & 20.2 & 670 & 60 \\
Erect dorycnium & 0.9 & 0.6 & 22.1 & 665 & nd \\
LSD (P<0.05) & 0.6 & 0.3 & 1.1 & 18 & 16 \\
\hline
\end{tabular}

nd, not determined.

Table 3 Edible forage yield from trees and pasture over the two harvesting periods in experiment 2.

\begin{tabular}{lccc}
\hline Forage types & Harvest period & $\begin{array}{c}\text { Edible forage yield } \\
\text { (kg DM/ha) }\end{array}$ & $\begin{array}{c}\text { \% contribution to } \\
\text { edible forage }\end{array}$ \\
\hline $\begin{array}{l}\text { Kinuyanagi willow } \\
\text { Tangoio hybrid }\end{array}$ & $\mathrm{S}+\mathrm{A}$ & 2245 & 29 \\
$\quad$ willow & $\mathrm{S}+\mathrm{A}$ & 2945 & 38 \\
$\begin{array}{l}\text { Erect dorycnium } \\
\text { Pasture }\end{array}$ & $\mathrm{S}+\mathrm{A}$ & 1650 & 22 \\
& January (S) & 430 & 11 \\
\hline
\end{tabular}

$\mathrm{S}+\mathrm{A}$ - Summer plus Autumn; edible pasture estimated as $70 \%$ of total live grass and legume yield. yields of Kinuyanagi (5.15 t DM/ha and $1.84 \mathrm{t} \mathrm{DM/ha)}$ to be more than those of Tangoio (4.32 t DM/ha and $1.19 \mathrm{t} \mathrm{DM} / \mathrm{ha})$. Also, total and edible DM yields in experiment 2 of our study were higher than in the experiments of Douglas et al. (1996). Nevertheless, the edible forage yield of Tangoio was less than the 3.2-5.7 t DM/ha found by Hathaway (1986). The differences were possibly due to the age of the plants at harvest. Our experiment involved 3-year-old trees compared with 1-year (Douglas et al. 1996) and 5-yearold trees (Hathaway 1986) in the earlier studies.

The practical implication is that as the trees aged, edible forage yield increased owing to increased 
coppiced stump diameter. Stur et al. (1994) found that cutting height did not affect the yield of a range of browse species. The advantage of cutting height not affecting yield is that the willows can be harvested at a height that keeps current growth within reach of browsing animals. Also in cut and carry systems, tree forage can be harvested conveniently leaving a short stool without any appreciable reduction in subsequent regrowth. The total DM yield of erect dorycnium (2.4 t DM/ha) equalled that found by Douglas et al. (1996) but provided twice as much edible forage $(1.7 \mathrm{t} \mathrm{DM} / \mathrm{ha}$ vs $0.8 \mathrm{t} \mathrm{DM} / \mathrm{ha}$ ). However, the low yield of the species limits its potential as a drought fodder in the lower North Island.

The low yields of both willows at Ballantrae may have been due to low soil fertility and harsh climatic conditions like low temperatures and strong winds (van Kraayenoord \& Hathaway 1986). Poor regrowth after the summer harvest suggested inadequate carbohydrate storage in the roots as a result of low above-ground primary growth (Menke \& Trlica 1981). Therefore, these willows may be utilised only once during the growing season in such environments and tree forage may be harvested manually or browsed in situ.

The use of unrooted stem cuttings for willows would reduce the initial capital outlay in establishing and managing the plants, and this stock type is recommended.

The high edible forage yield obtained from the browse plants, relative to pasture, was as expected at that time of the year (Lambert et al. 1989; Douglas et al. 1996). This fodder supplements the pasture and provides support for the inclusion of browse plants in some pastoral farming systems (Lambert et al. 1989).

Nitrogen contents of willows and erect dorycnium growing at Aokautere were above the recommended level in an adequate diet for a lactating ewe with a single lamb (NRC 1975). The organic matter digestibilities for Tangoio and Kinuyanagi in the two experiments were similar but that of Kinuyanagi $(613 \mathrm{~g} / \mathrm{kg} \mathrm{DM})$ was higher than estimates (400-500 g/ kg DM) reported by Douglas et al. (1996). The reasons for the lack of agreement between the values for Kinuyanagi were unclear, but they could involve condensed tannins and their effect on forage digestibility.

The condensed tannin levels of the willows were higher than for legumes like Hedysarum coronarium (34-38 g/kg DM) and Lotus corniculatus (19-24 g/kg DM) (Douglas et al. 1993). Total condensed tannin levels for the two willows were higher at Ballantrae than at Aokautere, possibly owing to the more stressful environment at Ballantrae (Douglas et al. 1993). The leaves of Tangoio, however, have an acceptable level of condensed tannin ( $45 \mathrm{~g} / \mathrm{kg} \mathrm{DM})$ for livestock and can, therefore, be browsed without any deleterious effects.
Despite the higher total CT of Kinuyanagi, sheep were observed browsing leaves and soft stems. McCabe \& Barry (1988) demonstrated that willow leaves were a nutritionally acceptable supplement to pasture for livestock during dry summers. In addition to its good forage quality and high yield, Tangoio is one of the most drought tolerant Salix spp. and may be established outside traditional growing areas (Douglas et al. 1996).

\section{Conclusions}

Tangoio and Kinuyanagi have potential as drought fodder in addition to their traditional roles in soil conservation and rehabilitation. Tangoio, especially the leaves, can be used as a maintenance feed for sheep during summer drought as a result of its satisfactory quality and edible forage yield during dry summers and early autumn. The potential role of Kinuyanagi willow as a supplementary drought fodder should not be discounted due to its higher condensed tannin level, because of its relatively high edible forage yield. The relatively low yield from erect dorycnium indicates that it will not provide adequate forage during dry summers in the lower North Island (Douglas et al. 1996). Tree growth is site dependent but unrelated to type of plant stock used. These preliminary studies suggest that further research on the browsing management and nutritional value of willows is required.

\section{ACKNOWLEDGEMENTS}

We thank Alex Foote, Roger Levy, Terry Lynch and Colin Stace for their technical assistance, the Foundation for Research, Science and Technology (Contract No. C10 539), Commonwealth Scholarship Scheme and Massey University Research Fund for financial support.

\section{REFERENCES}

Association of Official Agricultural Chemists (AOAC). 1984. Official methods of analysis. 14th ed. USA.

Douglas, G.B.; Donkers, P.; Foote, A.G.; Barry, T.N. 1993. Determination of extractable and bound condensed tannins in forage species. Proceedings of the XVII International Grassland Congress: 204-206.

Douglas, G.B.; Bulloch, B.T.; Foote, A.G. 1996. Cutting management of willows (Salix spp.) and leguminous shrubs for forage during summer. New Zealand journal of agricultural research 39: 175-184.

Hathaway, R.L. 1986. Short-rotation coppiced willows for sheep fodder in New Zealand. New Zealand journal of agricultural science 20: 140-142.

Lambert, M.G.; Jung, G.A.; Costall, C.A. 1989. Forage shrubs in North Island hill country. 1. Forage 
production. New Zealand journal of agricultural research 32: 477-483.

McCabe, S.M.; Barry, T.N. 1988. Nutritive value of willow (Salix sp.) for sheep, goats and deer. Journal of agricultural science, Cambridge 111: 1-9.

Menke, J.W.; Trlica, M.J. 1981. Carbohydrate reserve, phenology, and growth cycles of nine Colorado range species. Journal of range management 34 : 269-277.

NRC 1975. Nutrient requirements of sheep. National Academy of sciences, Washington D.C. 72p.

Roughan, P.G.; Holland, R. 1977. Predicting in vivo digestibilities of herbages by exhaustive enzymic hydrolysis of cell walls. Journal of the science of food and agriculture 28: 1057-1064.

SAS. 1988. SAS user's guide, release 6.03 edition. Statistical Analysis System Institute. Cary North Carolina, USA.
Stur, W.W.; Shelton, H.M.; Gutteridge, R.C. 1994. Defoliation Management of forage tree legumes. pp. 158-167. In: Gutteridge, R.C. and Shelton, H.M. (eds). Forage tree legumes in tropical agriculture. CAB International, U.K.

Terrill, T.H.; Rowan, A.M.; Douglas, G.B.; Barry, T.N. 1992. Determination of extractable and bound condensed tannin concentrations in forage plants, protein concentrate meals and cereal grains. Journal of the science of food and agriculture 58: 321-329.

van Kraayenoord, C.W.S.; Hathaway, R.L. 1986. Plant materials handbook for soil conservation. volume 1: Principles and Practices. Water and Soil miscellaneous publication no. 93, Soil Conservation Centre, Aokautere, Ministry of works and development, Palmerston North. 
